\title{
Pengaruh Pemberian Ekstrak Rimpang Temulawak (Curcuma Xanthorrhiza Roxb.) dan Jintan Hitam (Nigella Sativa) terhadap Profil Lipid Tikus Sprague Dawley Dislipidemia
}

\author{
Andika Agus Budiarto, ${ }^{1}$ Alem Pramudita Wibowo, ${ }^{1}$ Stella Andriana Putri, ${ }^{1}$ Nadine Nurani Shabrina, ${ }^{1}$ \\ Dwi Ngestiningsih, ${ }^{2}$ Kusmiyati Tjahjono $^{2}$ \\ ${ }^{1}$ Fakultas Kedokteran Universitas Diponegoro, ${ }^{2}$ Departemen Biokimia Fakultas Kedokteran Universitas \\ Diponegoro
}

\begin{abstract}
Abstrak
Terapi jangka panjang dislipidemia dengan simvastatin dapat menimbulkan berbagai efek samping sehingga perlu alternatif terapi, salah satunya dengan temulawak dan jintan hitam. Kandungan curcumin pada temulawak dan thymoquinon pada jintan hitam diperkirakan dapat memperbaiki profil lipid pasien dislipidemia. Tujuan dari penelitain adalah membuktikan efek pemberian ekstrak temulawak dan ekstrak jintan hitam terhadap profil lipid tikus Sprague dawley dislipidemia. Penelitian menggunakan true experimental design dengan post test randomized controlled group design. Penelitian ini dilakukan di Laboratorium Penelitian dan Pengujian Terpadu (LPPT)-Layanan Pra Klinik Pengembangan Hewan Percobaan (LP3HP) Universitas Gajah Mada Yogyakarta dan di Laboratorium Biologi Fakultas Sains dan Matematika Universitas Negeri Semarang periode 18 Februari-8 Maret 2016. Sebanyak 42 ekor tikus Sprague dawley dibagi menjadi 6 kelompok, yaitu kelompok K1 (kontrol normal), kelompok K2 (kontrol dislipidemia), kelompok P1 (200 mg/kgBB ekstrak temulawak), kelompok P2 (400 mg/kgBB ekstrak jintan hitam), kelompok P3 (0,18 mg/200 gramBB simvastatin), dan kelompok P4 (200 $\mathrm{mg} / \mathrm{kgBB}$ ekstrak temulawak dan $400 \mathrm{mg} / \mathrm{kgBB}$ ekstrak jintan hitam). Kadar kolesterol LDL, HDL dan kolesterol total diukur dengan CHOD-PAP. Hasil penelitian menunjukkan kelompok K2 memiliki kadar tertinggi kolesterol total $(69,1 \pm 2,41)$ dan LDL $(25,9 \pm 2,16)$, serta memiliki kadar terendah HDL $(30,68 \pm 5,25)$. Uji ANOVA pada kolesterol total dan LDL menunjukan perbedaan bermakna $(p<0,05)$, sedangkan pada HDL tidak bermakna $(\mathrm{p}>0,05)$. Disimpulkan, ekstrak temulawak dan ekstrak jintan hitam berpotensi menurunkan kadar LDL dan kolesterol total, serta menaikkan kadar HDL pada tikus Sprague Dawley dislipidemia. [MKB. 2017:49(1):8-14]
\end{abstract}

Kata kunci: Jintan hitam, profil lipid, temulawak

\section{Effects of Temulawak (Curcuma xanthorrhiza Roxb.) and Black Cumin (Nigella sativa) Extracts on Lipid Profile: A Study on Dyslipidemic Sprague Dawley Rats}

\begin{abstract}
The use of Simvastatin for a long term therapy of dyslipidemia can cause unwanted side effects; therefore, alternative therapies are needed, including therapy using temulawak and black cumin extracts. Curcumin in temulawak and thymoquinon in black cumin could modify the lipid profile of patients with dyslipidemia. The aim of study was to determine the effect of temulawak and black cumin extracts on serum lipid profile of dyslipidemic Sprague dawley rats. This research was conducted at Integrated Research and Testing Laboratory (PPT) -Profit Clinical Trials (LP3HP) Gadjah Mada University Yogyakarta and in Biology Laboratory Faculty of Science and Mathematics State University of Semarang period 18 February-8 March 2016. This study used true experimental design with post-test randomized controlled group design. Forty two Sprague dawley rats were divided into 6 groups: K1 for normal control, K2 for dyslipidemic control, P1 received 200mg/kgBW Temulawak extract, P2 received 400mg/ kgBW black cumin extract, P3 received $0.18 \mathrm{mg} / 200 \mathrm{grBW}$ simvastatin, and P4 received a combination of 200mg/ kgBW Temulawak extract and 400mg/kgBW black cumin extract. LDL, HDL, and total cholesterol levels were determined by CHOD-PAP. The results of this study showed that K2 group had the highest level of total cholesterol $(69.1 \pm 2.41)$ and LDL $(25.9 \pm 2.16)$ but the lowest level of HDL(30.68 \pm 5.25$)$ when compared to the other groups. ANOVA analysis of total cholesterol and LDL showed a significant difference $(p<0.05)$, while the sama analysis on HDL showed a non-significant difference ( $p>0.05)$. From the results, it is concluded that temulawak extract and black cumin extract can potentially decrease the level of LDL and total cholesterol as well as increasing the level of HDL in dyslipidemic Sprague Dawley rats. [MKB. 2017;49(1):8-14]
\end{abstract}

Key words: Black cumin, lipid profile, temulawak

Korespondensi: Andika Agus Budiarto, dr., Fakultas Kedokteran Universitas Diponegoro, Jalan Prof. Sudarto SH, Tembalang, Semarang, Jawa Tengah, mobile: 085851438645, e-mail: budiarto.andika@gmail.com 


\section{Pendahuluan}

Dislipidemia merupakan kondisi peningkatan kadar lemak dalam darah seperti small, dense low-density lipoprotein (LDL), dan trigliserida serta penurunan high-density lipoprotein (HDL). ${ }^{1}$ Hasil penelitian menyatakan bahwa sebagian besar penderita dislipidemia tidak terdiagnosis dan juga angka prevalensi kejadian penderita dislipidemia di sembilan negara mengalami peningkatan dengan rata-rata 1,76\% per tahun serta diperkirakan akan mencapai hingga 500 juta penderita pada tahun $2022 .^{2}$

Kondisi dislipidemia ini merupakan faktor penyebab utama penyakit kardiovaskular. World Health Organization (WHO) memperkirakan pada tahun 2020 angka kematian akibat dari penyakit kadiovaskular mencapai 23,6 juta orang terutama akibat penyakit jantung dan strok. ${ }^{3}$ Angka penderita penyakit jantung di Indonesia mencapai 2,6 juta pada tahun 2013, sedangkan penderita strok mencapai 530.000 orang. ${ }^{4}$

Pada keadaan ini pengobatan lini pertama dalam tata laksana dislipidemia menggunakan obat golongan statin contohnya simvastatin. ${ }^{5}$ Akan tetapi, pada pengobatan jangka panjang akan dapat menyebabkan efek samping seperti rabdomiolisis, mialgia, miositis, meningkatkan risiko kanker, strok hemoragik, dan gangguan kognitif. ${ }^{6}$ Akibat beberapa efek samping tersebut maka diperlukan alternatif dalam tata laksana dislipidemia, salah satunya dengan menggunakan tanaman herbal rimpang temulawak dan jintan hitam.

Rimpang temulawak mengandung beberapa komponen bioaktif, yaitu salah satunya adalah kurkumin. Kandungan kurkumin dalam rimpang temulawak dapat menghambat pembentukan LDL akibat induksi sel stelata hepar. ${ }^{7}$ Ekstrak temulawak juga dapat menurunkan konsentrasi trigliserida serum, fosfolipid, kolesterol hepar, serta dapat meningkatkan kolesterol HDL serum dan Apo A-I pada tikus dengan diet kolesterol tinggi. ${ }^{8}$ Jintan hitam pada penelitian tahun 2012 dinyatakan mampu menurunkan kadar trigliserida dan LDL serta menaikkan kadar HDL sehingga jintan hitam merupakan salah satu agen alami yang mencegah aterosklerosis dan penyakit kardiovaskular. ${ }^{9}$ Jintan hitam juga dapat melindungi kenaikan profil lemak dan glukosa darah yang risikonya meningkat selama proses menstruasi. ${ }^{10}$

Berdasarkan atas latar belakang tersebut maka penelitian ini bertujuan membuktikan efek pemberian dari kombinasi ekstrak rimpang temulawak (Curcuma xanthorrhiza roxb.) dan jintan hitam (Nigella sativa) terhadap profil lipid serum pada tikus Sprague Dawley dislipidemia.

\section{Metode}

Penelitian ini telah dilaksanakan selama delapan minggu mulai tanggal 18 Februari 2016 sampai 8 Maret 2016 di Laboratorium Penelitian dan Pengujian Terpadu (LPPT)-Layanan Pra Klinik Pengembangan Hewan Percobaan (LP3HP) Universitas Gajah Mada Yogyakarta dan juga di Laboratorium Biologi Fakultas Sains dan Matematika Universitas Negeri Semarang.

Metode pada penelitian ini menggunakan eksperimental murni dengan rancangan desain terkontrol teracak pada 42 binatang coba tikus Sprague Dawley yang dilakukan selama delapan minggu dan terbagi dalam dua kelompok, yaitu kelompok kontrol dan juga perlakuan tiap-tiap kelompok tujuh ekor tikus. Kriteria inklusi: tikus normal, bobot badan 150-250 gram, berumur 8 minggu sebelum diadaptasi, tikus dalam keadaan sehat dan aktif bergerak. Kriteria eksklusi: tikus mengalami diare, tikus tidak mau makan dan minum, terdapat kelainan anatomik dan tikus mati dalam masa penelitian.

Pada kelompok kontrol negatif dan positif diberikan perlakuan selama empat minggu, kemudian diperiksa kadar kolesterol LDL, dan HDL, serta kolesterol total serum. Kelompok perlakuan P1, P2, P3, dan P4 diberikan pakan tinggi lemak selama 4 minggu menambahkan lemak dengan jumlah lemak $10 \%$ dari pakan standar. Lemak terdiri atas kuning telur dan minyak babi dengan perbandingan 2:1. Setelah itu kelompok perlakuan dilanjutkan selama 4 minggu lagi dengan perlakuan yang berbeda, kemudian diperiksa kadar kolesterol LDL, HDL, dan kolesterol total serum.

Sampel darah diambil langsung dari vena pada pleksus retro-orbitalis setelah diberi perlakuan kemudian diperiksa kadar kolesterol LDL lewat proses enzimatik dengan metode CHOP-PAP (cholesterol oxydase-phenyl aminopyrazolon). Kadar kolesterol LDL diperiksa dengan rumus: Kadar cLDL=Kolesterol total-Presipitan LDL. Satuan yang digunakan adalah $\mathrm{mg} / \mathrm{dL}$.

Data dianalisis menggunakan uji statistik uji ANOVA one way untuk data berdistribusi normal dan uji Kruskal wallis untuk data tidak normal. Kemudian, data yang didapatkan diolah dengan program SPSS for windows. Uji lanjutnya menggunakan uji Post Hoc dan uji Mann Whitney untuk melihat perbedaan dari tiap kelompok. Data dinyatakan bermakna bila nilai $p<0,05$. 
Tabel 1 Pembagian Kelompok Kontrol dan Kelompok Perlakuan

\begin{tabular}{cl}
\hline Kelompok & \multicolumn{1}{c}{ Perlakuan } \\
\hline K1 & Kontol negatif dengan pakan standar \\
K2 & Kontrol positif dengan pakan tinggi lemak \\
P1 & Pakan tinggi lemak + ekstrak rimpang temulawak $200 \mathrm{mg} / \mathrm{kgBB}$ \\
P2 & Pakan tinggi lemak + ekstrak jintan hitam $100 \mathrm{mg} / \mathrm{kgBB}$ \\
P3 & Pakan tinggi lemak + simvastatin 0,18 mg $/ 200$ gram BB \\
P4 & Pakan tinggi lemak + ekstrak rimpang temulawak $200 \mathrm{mg} / \mathrm{kgBB}+$ ekstrak jintan \\
\hline
\end{tabular}

\section{Hasil}

Hasil uji normalitas Shapiro-Wilk adalah data berdistribusi normal $(p>0,05)$ sehingga ukuran pemusatan data yang digunakan adalah mean dan untuk penyebaran data digunakan standar deviasi.

Hasil penelitian ini menunjukkan kenaikan kadar kolesterol LDL dan kolesterol total serum rata-rata pada kelompok kontrol negatif (19,6 $\mathrm{mg} / \mathrm{dL} ; 54,9 \mathrm{mg} / \mathrm{dL})$ dibanding dengan kelompok kontrol positif $(25,9 \mathrm{mg} / \mathrm{L} ; 69,1)$. Kadar kolesterol HDL serum rata-rata pada kelompok kontrol negatif K1 (mean=36,84 mg/ dL) menunjukkan kadar kolesterol HDL yang lebih tinggi dibanding dengan kelompok kontrol positif K2 (mean=30,68 mg/dL).

Penelitian ini juga menunjukkan penurunan kadar kolesterol LDL dan kolesterol total serum antara kelompok yang tidak diberi ekstrak rimpang temulawak (K2=25,9 mg/dL; $69,1 \mathrm{mg} /$ dL) dan yang diberi ekstrak rimpang temulawak (P1=20,7 mg/dL; 54,2 mg/dL) serta kenaikan kadar kolesterol HDL antara kelompok yang tidak diberi ekstrak rimpang temulawak $(\mathrm{K} 2=$ $30,7 \mathrm{mg} / \mathrm{dL}$ ) dengan yang diberi ekstrak rimpang temulawak (P1=33,8 mg/dL) selama 4 minggu.

Hal yang sama dalam penelitian ini juga menunjukkan penurunan kadar kolesterol LDL dan kolesterol total serum antara kelompok yang tidak diberi ekstrak jintan hitam (K2=25,9 $\mathrm{mg} / \mathrm{dL} ; 69,1 \mathrm{mg} / \mathrm{dL}$ ) dan yang diberi ekstrak jintan hitam (P2=17,8 mg/dL; 66,0 mg/dL) serta kenaikan kadar kolesterol HDL antara kelompok yang tidak diberi ekstrak jintan hitam (K2=30,7 $\mathrm{mg} / \mathrm{dL}$ ) dan yang diberi ekstrak jintan hitam (P2=32,2 mg/dL) selama 4 minggu.

Kelompok P3 dengan perlakuan simvastatin juga menunjukkan penurunan kadar kolesterol LDL dan kolesterol total serum antara kelompok yang tidak diberikan simvastatin $(\mathrm{K} 2=25,9$ $\mathrm{mg} / \mathrm{dL} ; 69,1 \mathrm{mg} / \mathrm{dL}$ ) dan kelompok yang diberi simvastatin (P3 = 17,7 mg/dL; 57,4 mg/dL) serta kenaikan kadar kolesterol HDL antara kelompok yang tidak diberi simvastatin $(\mathrm{K} 2=30,7 \mathrm{mg} / \mathrm{dL})$ dan yang diberi simvastatin $(\mathrm{P} 3=31,9 \mathrm{mg} / \mathrm{dL}$ ) selama 4 minggu.

Pada kelompok P4 juga menunjukkan hasil yang sama dengan kelompok perlakuan yang lain, yaitu terdapat penurunan kadar kolesterol LDL dan kolesterol total serum antara kelompok yang tidak diberikan kombinasi $(\mathrm{K} 2=25,9 \mathrm{mg} /$ $\mathrm{dL} ; 69,1 \mathrm{mg} / \mathrm{dL}$ ) dan kelompok yang diberi kombinasi ekstrak rimpang temulawak dan jintan hitam (P4 = 18,8 mg/dL; 62,5 mg/dL) serta kenaikan kadar kolesterol HDL antara kelompok yang tidak diberi kombinasi $(\mathrm{K} 2=30,7 \mathrm{mg} / \mathrm{dL})$ dengan yang diberi kombinasi ekstrak rimpang temulawak dan jintan hitam (P4 = 32,3 $\mathrm{mg} / \mathrm{dL})$ selama 4 minggu.

Tabel 2 Kadar kolesterol LDL, HDL, dan Koleterol Total Serum (mean \pm SD) pada Kelompok Kontrol dan Perlakuan

\begin{tabular}{lcccccc}
\hline $\begin{array}{c}\text { Kadar Kolesterol } \\
\begin{array}{c}\text { Serum } \\
\text { (mean } \pm \text { SD (mg/dL) }\end{array}\end{array}$ & K1 & K2 & P1 & P2 & P3 & P4 \\
\hline LDL & $19,6 \pm 3,11$ & $25,9 \pm 2,16$ & $20,7 \pm 2,80$ & $17,8 \pm 5,26$ & $17,7 \pm 3,12$ & $18,8 \pm 3,10$ \\
HDL & $36,8 \pm 5,00$ & $30,7 \pm 5,25$ & $33,8 \pm 3,11$ & $32,2 \pm 6,33$ & $31,9 \pm 6,33$ & $32,3 \pm 2,16$ \\
Kolesterol total & $54,9 \pm 4,80$ & $69,1 \pm 2,41$ & $54,2 \pm 3,24$ & $66,0 \pm 14,59$ & $57,4 \pm 5,95$ & $62,5 \pm 7,95$ \\
\hline
\end{tabular}

Keterangan: kolesterol LDL: p=0,007; Uji one way ANOVA; kolesterol HDL p=0,277 uji Kruskal-Walls; Kolesterol total: $p=0,033$ uji Kruskal-Walls 


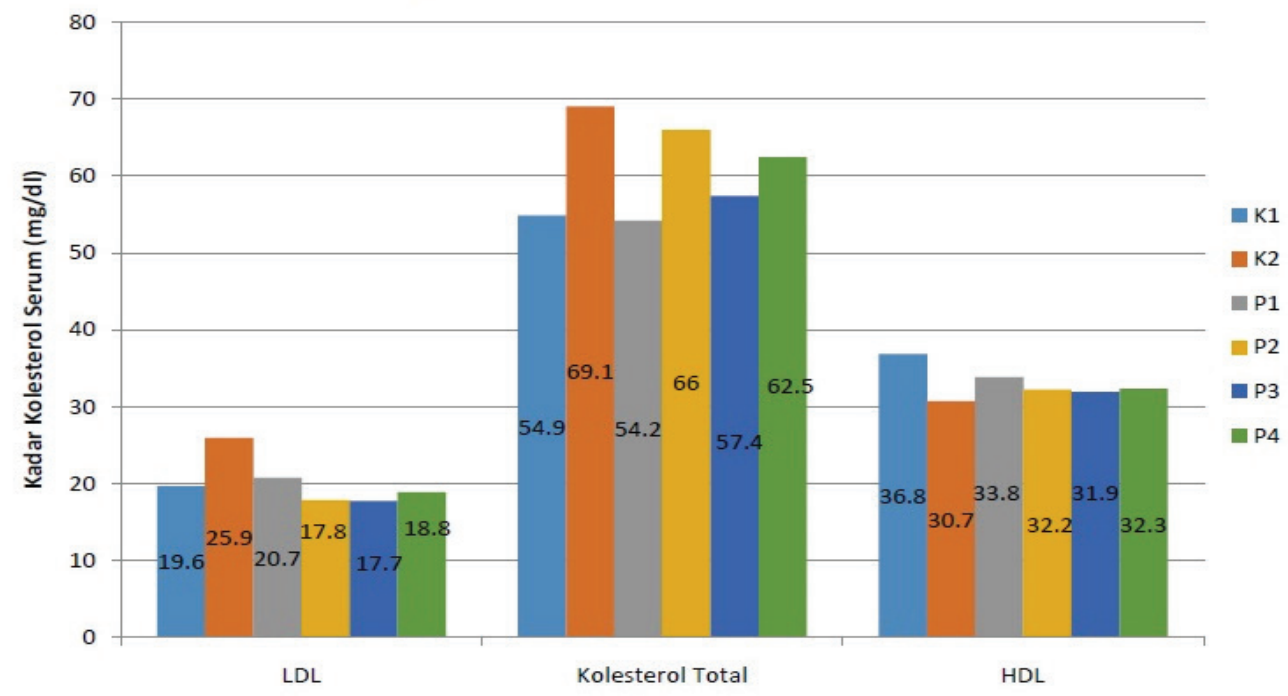

\section{Gambar Grafik Perbandingan Kadar Kolesterol LDL, HDL, dan Kolesterol Total Serum Rata-rata antar Kelompok Perlakuan dan Kelompok Kontrol}

Selanjutnya, untuk mengetahui kelompok mana yang terdapat perbedaan bermakna maka dilanjutkan dengan uji analisis Post Hoc kadar kolesterol LDL dan kolesterol total, sedangkan kadar kolesterol HDL dilakukan uji analisis Post Hoc karena tidak didapatkan perbedaan yang signifikan.

Pada kelompok kontrol (Tabel 3), kadar kolesterol LDL serum pada kelompok kontrol negatif (K1) yang mendapat diet pakan standar dibanding dengan kelompok kontrol positif (K2) yang diberi pakan tinggi lemak menunjukkan peningkatan yang signifikan $(p=0,00)$. Pada kelompok kontrol positif (K2) jika dibanding dengan dengan kelompok perlakukan ekstrak temulawak (P1), kelompok perlakuan ekstrak jintan hitam (P2), dan kelompok perlakuan simvastatin (P3), serta kelompok perlakuan kombinasi ekstrak temulawak dan jintan hitam (P4) menunjukan penurunan kadar kolesterol LDL serum yang bermakna karena $\mathrm{p}<0,05(\mathrm{p}=$ 0,$02 ; \mathrm{p}=0,00 ; \mathrm{p}=0,00$; dan $\mathrm{p}=0,00$ ). Pemberian ekstrak temulawak dan jintan hitam dengan dosis tunggal bila dibanding dengan pemberian kombinasi ekstrak temulawak dan jintan hitam menunjukkan hasil perbedaan tidak signifikan $(\mathrm{p}=0,38$ dan $\mathrm{p}=0,66)$. Begitu juga perbandingan antara pemberian simvastatin dibanding dengan pemberian ekstrak temulawak dan jintan hitam baik dalam dosis tunggal maupun kombinasi ( $\mathrm{p}$ $=0,17 ; \mathrm{p}=0,98$ dan $\mathrm{p}=0,63)$.

Pada uji Post Hoc tiap-tiap kelompok (Tabel 4) terdapat perbedaan yang bermakna kadar kolesterol total antara kelompok KI dan K2

Tabel 3 Nilai p Uji Statistik Post Hoc Kadar Kolesterol LDL Serum

\begin{tabular}{|c|c|c|c|c|c|}
\hline $\begin{array}{c}\text { Kadar Kolesterol tiap } \\
\text { Kelompok } \\
(\text { mean } \pm \text { SD }(\mathrm{mg} / \mathrm{dL})\end{array}$ & K2 & P1 & P2 & P3 & P4 \\
\hline K1 & $0,00^{*}$ & 0,60 & 0,37 & 0,33 & 0,67 \\
\hline P1 & $0,02^{*}$ & - & 0,19 & 0,17 & 0,38 \\
\hline P2 & $0,00^{*}$ & 0,19 & & 0,98 & 0,66 \\
\hline P3 & $0,00^{*}$ & 0,98 & 0,98 & - & 0,6 \\
\hline P4 & $0,00^{*}$ & 0,66 & 0,66 & 0,63 & \\
\hline
\end{tabular}

*Perbedaan signifikan $(\mathrm{p}<0,05)$ uji post hoc; K1 pakan standar; K2: pakan tinggi lemak; P1: pakan tinggi lemak+ekstrak rimpang temulawak $200 \mathrm{mg} / \mathrm{kgBB}$; P2: pakan tinggi lemak+ekstrak jintan hitam $400 \mathrm{mg} / \mathrm{kgBB}$; P3: pakan tinggi lemak+simvastatin 0,18 mg/200 gram BB; P4: pakan tinggi lemak+ektrak rimpang temulawak $200 \mathrm{mg} / \mathrm{kgBB}+\mathrm{ektrak}$ jintan hitam $400 \mathrm{mg} / \mathrm{kgBB}$ 
Tabel 4 Analisis Post Hoc Kadar Kolesterol Total Tiap Kelompok

\begin{tabular}{lccccc}
\hline $\begin{array}{c}\text { Kadar Kolesterol Tiap } \\
\text { Kelompok } \\
\text { (mean } \pm \text { SD (mg/dL) }\end{array}$ & K2 & P1 & P2 & P3 & P4 \\
\hline K1 & $0,003^{*}$ & 0,964 & 0,015 & 0,508 & 0,083 \\
P1 & $0,005^{*}$ & - & 0,021 & 0,515 & 0,099 \\
P2 & $0,528^{*}$ & 0,021 & & 0,069 & 0,469 \\
P3 & $0,016^{*}$ & 0,515 & 0,069 & - & 0,270 \\
P4 & $0,181^{*}$ & 0,099 & 0,469 & 0,270 & - \\
\hline
\end{tabular}

*(p<0,05) post hoc analisis; K1 kelompok kontrol negatif; K2 kelompok kontrol positif; P1: kelompok perlakuan ekstrak rimpang temulawak; P2: kelompok perlakuan ekstrak jintan hitam; P3: kelompok perlakuan simvastatin; P4: kelompok perlakuan ekstrak temulawak dan jintan hitam

( $p=0,003$ ). Perbandingan kelompok kontrol K2, dengan seluruh kelompok perlakuan didapatkan perbedaan yang bermakna terhadap kelompok K2 dengan P1 $(p=0,005)$ dan kelompok K2 dengan P3 $(p=0,016)$. Apabila membandingkan antara kelompok perlakuan, terdapat perbedaan bermakna antara kelompok P1 dan P2 ( $\mathrm{p}=0,021)$.

\section{Pembahasan}

Pada penelitian ini pemberian pakan tinggi lemak mampu memberi gambaran dislipidemia, yaitu terjadi peningkatan kadar kolesterol LDL dan kolesterol total serta penurunan kadar kolesterol HDL. Hal yang sama juga dinyatakan dalam penelitian yang dilakukan oleh Harsa ${ }^{11}$ bahwa dengan pemberian diet tinggi lemak berupa lemak babi sebanyak 3 gram/200 gram $\mathrm{BB} /$ hari dengan kuning telur sebanyak 2 gram/200 gram BB/hari pada tikus putih selama empat minggu mampu meningkatkan kadar kolesterol total, kolesterol LDL, trigliserida, serta menurunkan kadar kolesterol HDL. Peningkatan ini disebabkan oleh kandungan kolesterol yang tinggi dalam minyak babi dan kuning telur yang dapat menyebabkan absorbsi kolesterol di dalam usus meningkat dan meningkatkan sintesis LDL di hepar sehingga terjadi peningkatan kadar kolesterol LDL serum tikus.

Kelompok dengan pemberian ekstrak rimpang temulawak menunjukkan hasil penurunan kadar kolesterol LDL dan kolesterol total karena dalam rimpang temulawak mengandung senyawa curcumin ${ }^{12}$ Senyawa curcumin ini menstimulasi enzim hepatic cholesterol-7 $\alpha$-hydroxylase atau CYP7A1. Enzim ini mengkatalisasi perubahan kolesterol menjadi garam empedu yang terdapat di dalam sel hati. Peningkatan aktivitas enzim ini akan mengakibatkan peningkatan katabolisme kolesterol. Peningkatan katabolisme kolesterol ini menurunkan kadar kolesterol dalam hati sehingga akan meningkatkan ambilan LDL dalam plasma oleh reseptor LDL, dengan demikian maka kadar LDL plasma akan turun. ${ }^{13}$ Kadar kolesterol LDL menurun juga disebabkan oleh curcumin dapat mengaktivasi kerja peroxisome proliferator-activated receptor- $\gamma$ (ppar $\gamma$ ) yang dapat meningkatkan produksi sterol regulatory element-binding proteins-1 (SRBP-1) di hati sehingga terjadi kenaikan jumlah reseptor LDL dan menurunkan kadar kolesterol LDL. Selain itu dengan teraktivasinya PPAR $\gamma$ juga dapat meningkatkan kadar kolesterol HDL melalui stimulus PPAR $\alpha,{ }^{7,14}$

Pada kelompok dengan pemberian jintan hitam juga memperlihatkan penurunan kadar kolesterol LDL dan kolesterol total serum tikus ini disebabkan oleh karena sinergisitas dari aktivitas beberapa komponen dalam jintan hitam seperti thymoquinone (TQ), flavonoid, dan polyunsaturated fatty acids (PUFAs). Kandungan TQ yang terdapat dalam jintan hitam ini dapat menurunkan lipid plasma dengan supresi aktivitas HMGKoA reduktase dan meningkatkan jumlah resptor LDL serta dapat menghambat peroksidasi lipid dengan cara nonenzimatik di lisosom. ${ }^{15}$ Flavonoid juga berperan menurunkan sintesis kolesterol dan menekan reactive oxygen species (ROS), pembentukan nitrogen species, serta melindungi sistem antioksidan endogen. Flavonoid meningkatkan efisiensi sel hepar untuk menghilangkan kolesterol LDL dalam sirkulasi darah dengan meningkatkan jumlah reseptor LDL dan berikatan dengan Apo B. Kandungan PUFA yang tinggi dalam $N$. sativa berperan menurunkan total kolesterol. ${ }^{16}$

Perbandingan antarkelompok menunjukkan bahwa kadar kolesterol LDL serum tikus terendah pada kelompok perlakuan P3 yang 
diberikan simvastatin. Hasil ini juga sesuai atau sama dengan hipotesis penulis bahwa simvastatin dapat menurunkan kadar kolesterol LDL serum. Hasil ini juga sama dengan penelitian yang dilakukan oleh Tanideh and Badiei ${ }^{17}$ yang menyatakan bahwa pemberian simvasatin selama 2 bulan pada tikus yang diberikan diet tinggi lemak dapat menurunkan kadar kolesterol LDL serum yang signifikan. Penelitian yang dilakukan oleh Harini dan Astirin ${ }^{18}$ menyatakan bahwa tikus yang telah mendapat perlakuan simvastatin dengan dosis $1,09 \mathrm{~mL} / 270$ gramBB tanpa pemberian pakan tinggi lemak selama 2 minggu dapat menurunkan kadar kolesterol LDL serum hingga 28\%. Penurunan ini dikarenakan simvasatin bekerja dengan cara menghambat enzim HMGKoA reduktase dan mengakibatkan penurunan sintesis kolesterol dan juga terjadi peningkatan reseptor LDL pada membran hepatosit. Dengan efek hambatan enzim HMGCOA reductase juga dapat menurunkan kadar kolesterol total dan menaikkan kadar kolesterol HDL. ${ }^{19}$

Hasil yang sama juga dapat dilihat pada kelompok P4, yaitu dengan pemberian kombinasi ekstrak rimpang temulawak dan jintan hitam menunjukkan penurunan kadar kolesterol LDL dan kolesterol total, serta penurunan kadar kolesterol HDL. Hasil tersebut mendukung hipotesis penulis bahwa didapatkan penurunan kadar kolesterol LDL dan kolesterol total serta peningkatan kadar kolesterol HDL serum pada tikus Sprague Dawley jantan dengan pakan tinggi lemak setelah diberikan kombinasi ekstrak rimpang temulawak bersama dengan ekstrak jintan hitam selama 4 minggu. Penelitian lain yang dilakukan oleh Al-Nazawi dan El-Bahr ${ }^{20}$ bahwa pemberian curcumin dari ekstrak kunyit (Curcuma longa) dan jintan hitam selama 6 minggu pada tikus putih dengan dosis masingmasing 10 gram kg-1 dapat menurunkan kadar kolesterol LDL dan kolesterol total serta meningkatkan kadar kolesterol HDL serum secara signifikan. Penelitian lain menyatakan bahwa terdapat penurunan yang signifikan kadar kolesterol LDL dan kolesterol total serum dengan pemberian kombinasi kunyit dosis 1,5 gram/ kgBB dan jintan hitam 0,3 gram/kgBB pada tikus Sprague Dawley jantan yang mengalami sindrom metabolik akibat induksi diet fruktosa selama 6 minggu. ${ }^{21}$ Berdasar atas hal tersebut dapat dikatakan bahwa pemberian kombinasi ekstrak rimpang temulawak dan jintan hitam dapat menurunkan kadar kolesterol LDL dan kolesterol total serum serta meningkatkan kadar kolesterol HDL serum.
Simpulan, bahwa ekstrak rimpang temulawak dan jintan hitam berpotensi dapat menurunkan kadar kolesterol LDL dan kolesterol total serta menaikkan kadar kolesterol HDL pada tikus Sprague Dawley dislipidemia.

\section{Daftar Pustaka}

1. Musunuru K. Atherogenic Dyslipidemia: cardiovascular risk dietary intervention. Lipids. 2010;45(10):907-14.

2. Comanor WS, Scherer FM. Mergers and innovation in the pharmaceutical industry. J Heal Eco. 2013;32(1):106-13.

3. Nelson RH. Hyperlipidemia as a risk factor for cardiovascular disease. Prim Care. 2013;40(1):195-211.

4. Wang M, Wang F, Wang Y, Ma X, Zhao M, Zhao C. Metabonomics study of the therapeutic mechanism of gynostemma pentaphyllum and atorvastatin for hyperlipidemia in rats. PLoS One. 2013;8(11):1-10.

5. Katzung BG. Farmakologi dasar dan klinik. Edisi ke-10 Jakarta: Buku Kedokteran EGC; 2012.

6. Chandra KS, Bansal M, Nair T, Iyengar SS, Gupta R, Manchanda SC, dkk. Consensus statement on management of dyslipidemia in Indian subjects. Indian Heart J. 2014; 66(Suppl 3):S1-51.

7. Kang Q, Chen A. Curcumin suppresses expression of low-density lipoprotein (LDL) receptor, leading to the inhibition of LDLinduced activation of hepatic stellate cells. $\mathrm{Br}$ J Pharmacol. 2009;157(8):1354-67.

8. Itokawa $\mathrm{H}$, Shi $\mathrm{Q}$ Akiyama $\mathrm{T}$, MorrisNatschke SL, Lee K-H. Recent advances in the investigation of curcuminoids. Chin Med. 2008;3:11.

9. Kaatabi H, Bamosa AO, Lebda FM, Al Elq AH, Al-Sultan AI. Favorable impact of Nigella sativa seeds on lipid profile in type 2 diabetic patients. J Family Community Med. 2012;19(3):155-61.

10. Ibrahim RM, Hamdan NS, Ismail M, Saini SM, Abd Rashid SN, Abd Latiff L, dkk. Protective effects of nigella sativa on metabolic syndrome in menopausal women. Adv Pharm Bull. 2014;4(1):29-33.

11. Harsa IMS. Efek pemberian diet tinggi lemak terhadap profil lemak darah tikus putih (Rattus norvegius). Ilm Kedokt. 2014;3(1).

12. Kim MB, Kim C, Song Y, Hwang JK. Antihyperglycemic and anti-inflammatory effects of standardized curcuma xanthorrhiza 
roxb. extract and its active compound xanthorrhizol in high-fat diet-induced obese mice. Evid Based Complement Alternat Med. 2014;2014(1):1-10.

13. Fan C, Wo X, Dou X, Xu L, Qian Y, Luo Y, dkk. Regulation of LDL receptor expression by the effect of curcumin on sterol regulatory element pathway. Pharmacol Rep. 2006; 58(4):577-581.

14. Shiddiqui AM, Cui X, Wu R, Dong W, Zhou M, Hu M, dkk. The anti-inflammatory effect of curcumin in an experimental model of sepsis is mediated by up-regulation of peroxisome proliferator-activated receptor- $\gamma$. Crit Care Med. 2006;34(7):1874-82.

15. Al-Naqeep G, Ismail M, Yazan LS. Effects of thymoquinone rich fraction and thymoquinone on plasma lipoprotein levels and hepatic low density lipoprotein receptor and 3-hydroxy-3-methylglutaryl coenzyme A reductase genes expression. J Functional Foods. 2009;1(3):298-303.

16. Ramadan MF, Mörsel JT. Characterization of phospholipid composition of black cumin (Nigella sativa L.) seed oil. Nahrung. 2002;46(4):240-4.

17. Tanideh N, Badiei R. Evaluation of the effects of simvastatin alone and in combination with garlic on lipid profile and liver enzymes in rats fed normal and fat rich diet. MiddLeEast J Sci Res. 2013;15(9):1237-41.

18. Harini M, Astirin OP. Blood cholesterol levels of hypercholesterolemic rat (Rattus norvegicus) after VCO treatment. Nusantara Biosci. 2009;1(2):53-8.

19. Bogman K, Peyer AK, Török M, Küsters E, Drewe J. HMG-CoA reductase inhibitors and P-glycoprotein modulation. Br J Pharmacol. 2001;132(6):1183-92.

20. Al-Nazawi MH, El-Bahr SM. Hypolipidemic and Hypocholestrolemic effect of medical plant combination in the diet of rats : black cumin seed (Nigella sativa) and Turmeric (Curcumin). J Anim Vet Adv. 2012; 11(12):2013-9. 